Ben McCann

"Une force qui va": Reflections on Gérard Depardieu in Danton

Australian Journal of French Studies, 2021; 58(1):88-99

(C) 2021 Liverpool University Press

Originally published at: http://doi.org/10.3828/ajfs.2021.08

\title{
PERMISSIONS
}

https://www.liverpooluniversitypress.co.uk/pages/open-access-journals/

\section{Green Open Access}

Liverpool University Press Policy:

On authors archiving their work in open access repositories as "pre-prints" [publishing material where a pre-print or working paper has been previously mounted online]:

Author cannot archive pre-print (i.e. pre-refereeing)

On authors archiving their article in open access repositories as "post-prints" or "author accepted manuscripts" [with changes and modifications due to peer-review comments integrated into the text]:

Subject to the restrictions below, the author can archive the post-print/AAM (i.e. final draft postrefereeing) but there are special restrictions/conditions which apply to these rights

Special restrictions or conditions which apply to these rights:

Publisher's version/PDF cannot be used

Publisher copyright and source must be acknowledged

Must link to publisher version

Non commercial

On a non-profit server

\section{July 2021}




\title{
"Une force qui va": \\ Reflections on Gérard Depardieu in Danton
}

BEN McCANN

\begin{abstract}
Taking as its starting point a 1978 article by film critic Molly Haskell, in which she described Gérard Depardieu as "tactile [...] grasping, eating, touching, coming to physical terms with everything in sight", this article will consider a largely overlooked Depardieu role, as the committed revolutionary leader Georges Danton in Andrzej Wajda's Danton (1983) - a historical role which reflects the actor's commitment to the relevance of the Revolutionary politician and intellectual. By examining three key scenes, we scrutinize Depardieu's acting style (body language, vocal delivery, movement choices) and demonstrate how he is committed to new ways of engaging with the ideological processes of acting. In Danton, Depardieu pivots between a familiar set of performative registers - physical menace and selfregarding sensitivity, timidity and flamboyance, innocence and cunning-and so the performance ultimately serves as a timely reminder of his enduring mythic status in French cinema.
\end{abstract}

The most effective actors $[\ldots]$ in the cinema are those who can achieve such a degree of external and internal relaxation while being filmed that the camera records their nature without defining it. ${ }^{1}$

In 1993, Gérard Depardieu was termed "axiomatic", due to his ability to "crystallize and project cultural and social values" and display talent, versatility and a coherent screen image over a sustained period. ${ }^{2}$ A decade later, Guy Austin reminded us that Depardieu was by now so synonymous with French cinema, and that his star image had become so pervasive and so recognizable, that it had "ossified into a myth". ${ }^{3}$ More recently, Sue Harris, noting how Depardieu had become physically and morally compromised by the triple effects of ageing, commercial expediency and political vacillation, provocatively asked whether he now retained any further relevance as either a performer or a generational signifier in French cultural life. ${ }^{4}$ But it is this telling observation made back in 1978 by the American feminist film critic Molly

\footnotetext{
${ }^{1}$ David Thomson, Movie Man (New York: Stein and Day, 1967), p. 123.

${ }^{2}$ Ginette Vincendeau, "Gérard Depardieu: The Axiom of Contemporary French Cinema", Screen, 34: 4 (1993), 343-361 (p. 344).

${ }^{3}$ Guy Austin, "Threat or reassurance? Gérard Depardieu and Patrick Dewaere", in Stars in Modern French Film (London: Arnold, 2003), p. 78.

${ }^{4}$ Sue Harris, "Degraded divinity? Sacred monstrosity? Gérard Depardieu and the abject star body", Screen, 56: 3 (2015), 319-334.
} 
Haskell about Depardieu that seems, in 2020, unusually apposite: having just interviewed him, she describes the actor as "tactile, curious, a child discovering the world, inching and shoving along, grasping, eating, touching, coming to physical terms with everything in sight". ${ }^{5}$ Haskell is here partly talking about two components fundamental to Depardieu's screen personamovement and feeling, both in perpetual, interconnected motion. Her observation also highlights the physical, the palpable and the uninhibited, which remain the hallmark of Depardieu's public and on-screen persona, whether as the trademark bon viveur in Bon Appetit: Gérard Depardieu's Europe (2015-2016), the gregarious chat-show guest nonchalantly recounting how he publicly urinated into a bottle as his plane prepared for take-off, or as the wonderfully mischievous new age relationship therapist in Un beau soleil intérieur (2017), advising Juliette Binoche's character: "soyez open". Each time, to quote Haskell again, Depardieu appears "extraordinarily modern".

After nearly fifty years, then, Depardieu's status and his continued relevance to French cultural life resonate still. It has become commonplace to frame the essence of his dramatic persona in binary terms: from film to film, he is both the macho and the feminine, pivoting between physical threat and self-regarding thoughtfulness, timidity and flamboyance, innocence and cunning, frequently evoking the "romanticism of suffering". ${ }^{6}$ These competing star qualities are often on show in Depardieu's mid-career films (roughly, the early eighties to the late nineties), where he repeatedly played historical and fictional figures either hounded or obsessed, by himself or others. Whether incarnating Christopher Columbus, Vatel, Jean Valjean, the Count of Monte Cristo, Obélix, Alexandre Dumas, Porthos or Vidocq, in each case, Depardieu embodies a kind of mise en spectacle of national values and a reassuring,

\footnotetext{
${ }^{5}$ Molly Haskell, "You Gérard, Me Jane”, Film Comment, 14: 2 (March/April 1978), p. 23.

${ }^{6}$ Vincendeau, p. 353. For instance, in 2014, Depardieu starred in Welcome to New York as a thinly disguised version of disgraced IMF president Dominique Strauss-Kahn; in 2015 he played a grieving father in Valley of Love. Both films endlessly display the actor's sagging body and laboured breathing.
} 
universalized presence, within both the ecosystem of popular and heritage French cinema and the broader socio-realities of a changing Hexagon.

This article will look closely at a largely overlooked Depardieu role, as the revolutionary leader Georges Danton in Andrzej Wajda's Danton (1983). Taking this portrayal of a political figure as its primary focus, the following analysis of Depardieu's acting style (movement, vocal delivery, choices made to inflect character) aims to demonstrate how he imagines new ways of engaging with the ideological processes of acting. The reason for choosing to examine Depardieu's performance in Danton, apart from the fact that it has not drawn as much attention as it warrants, is that this manifestation of a historical figure reflects Depardieu's commitment to the role and relevance of the public intellectual. The performance serves too as a timely reminder of Depardieu's enduring mythic status in French cinema.

The following discussion is motivated by a set of questions. As an actor, what does Depardieu actually "do"? How does he act? What can we learn from a close study of aspects of his posture, gesture, use of space or overall intonation in a particular scene? What does his internalized and externalized style-that is, his concentration on small facial and vocal mannerisms or his use of body language, both to convey the "meaning" of the scene-tell us about the status of his acting in French cinema? Analysing his performance in Loulou (1980), Vincendeau notes how Depardieu "makes use of the bulk of his body as 'metaphysical' weight, with the added intensity of a minimalist acting style", ${ }^{7}$ while Phil Powrie suggests that Depardieu's acting style "relies heavily on being located within a context against which he usually rebels". ${ }^{8}$ This is the closest critics have come to pinning down the essence of the actor's craft. The central aspects of Depardieu's stardom are easily defined, and are by now well established-Richard Brody's profile in The New Yorker characterized Depardieu's dramatic

\footnotetext{
${ }^{7}$ Vincendeau, p. 354.

${ }^{8}$ Phil Powrie, Jean-Jacques Beineix (Manchester: Manchester University Press, 2001), p. 98.
} 
persona as "feral power, combined with a wounded sensibility and flayed vulnerability". ${ }^{9}$ Most classifications of Depardieu's stardom follow this line, and yet evaluations of his acting style remain curiously underdeveloped. This is partly due to the marginalized status film studies tends to assign screen performance in comparison to authorship, production design and mise en scène, and partly due to the way acting is commonly perceived as a mystical, deeply personal (and invisible) set of choices made by an actor who necessarily blurs the process of performance by refusing to explain or justify their craft. But as Brenda Austin-Smith reminds us, "acting matters"; in order to be fully valued, "performance must be noticed and identified as performance, rather than as star exhibition [...] or the traces of someone merely living in front of the camera". ${ }^{10}$

Studies of Depardieu's star persona always start with the voice. Nick Pinkerton argued in 2017 that Depardieu "packs more depth of feeling into one disappointed exhalation of a line than most actors could get out of a meaty monologue". ${ }^{11}$ Others have remarked on his voice's "tenderness and hesitancy", ${ }^{12}$ and how its "softness and subtle modulations provid[e] a contrast to the size of his body". ${ }^{13}$ But what does Depardieu do with his body? Three "committed moments" in Danton hold the key to answering this question. In these moments, politics, the focus on the internal and the external, and the ideology of performance triangulate in a vigorous, exhilarating way. Each scene underscores how Depardieu is able to mobilize voice and body. Two of these moments are brief; the other more sustained. By focusing on his micro-gestures, we may not just appreciate Depardieu's craft, but observe how his kinetic energy-une force

\footnotetext{
9 Richard Brody, "Gérard Depardieu's Shining Moments", The New Yorker, 18 February 2013, https://www.newyorker.com/culture/richard-brody/grard-depardieus-shining-moments (accessed 4 June 2020).

${ }^{10}$ Brenda Austin-Smith, "Acting Matters: Noting Performance in Three Films”, in Aaron Taylor (ed.), Theorizing Film Acting (New York \& London: Routledge, 2012), pp. 19-32 (p. 19).

11 Nick Pinkerton, "Interview: Gérard Depardieu", Film Comment, 5 October 2017, https://www.filmcomment.com/blog/interview-gerard-depardieu/ (accessed 12 October 2020).

12 Austin, p. 80.

${ }^{13}$ Ginette Vincendeau, Stars and Stardom in French Cinema (London: Continuum, 2000), p. 229.
} 
qui va-lends performative consistency to his work and offers an authorial imprint from role to role.

\section{The "committed" actor}

Depardieu works - hard, prodigiously, excessively. In this sense, he is France's most committed of actors, continuously shuttling between projects, cutting across genres, working with established auteurs, guaranteeing commercial success to smaller, less commercial projects, and toggling between television series, animation voicing, theatre and films. This form of prolific commitment has never been in doubt-upwards of 200 films, with four in postproduction in 2020 alone. For global audiences, Depardieu is French cinema. He has the best career of any French actor, primarily because he has never stopped working. ${ }^{14}$ Can we argue that it is improper to work so much? Does the sheer volume of Depardieu's filmography trump a personal "style" or thematic consistency, impeding the emergence of a coherent personal commitment to each project? The "raw, direct energy" noticed by Haskell in 1978 compels Depardieu to never stop. There is something profoundly professional about Depardieu in the way he moves from assignment to assignment, dutifully attending publicity junkets, public screenings and chat shows. This commitment derives in part from lies Depardieu's well-known tumultuous formative years — his troubled upbringing, juvenile delinquency — and from a fierce obligation to assist others by having his name attached to projects. ${ }^{15}$ His physicality, vocal delivery and command of the filmic space are a constant reminder of his presence. Depardieu has aged, but he has not changed.

"Committed" is also a useful way of analysing the performative nuances of Depardieu's acting style. Commitment in acting often implies being a Method actor, that acting technique

\footnotetext{
${ }^{14}$ On forging a career, Depardieu recalls advice he once received from fellow actor Marcel Dalio (1899-1983): "'You have to say "Yes," even if you don't understand what they're saying. You say "Yes." I did my American career without language, but I said 'Yes'." In Pinkerton, 2017.

${ }^{15} \mathrm{He}$ appeared in Mammuth (2010), for instance, without accepting a salary.
} 
that "stresses truthful behaviour in imaginary circumstances" and "trains the actor to make demands on the body through the use of stimuli and imagination". ${ }^{16}$ However, this is not how Depardieu works. His commitment to the roles he plays is not telegraphed through corporeal transformation or altered speech or accent. Instead, the authenticity comes from the simplicity and lack of pretension. The key moments in his films oscillate between guilelessness and absolute control: the bowling alley scene in Les Valseuses (1974), the "Tu manges?" scene in Tais-toi (2003), or the slow, deliberate walk he takes across a Death Valley motel lawn towards Isabelle Huppert in Valley of Love (2015). These are all choices made by Depardieu that may or may not appear in the original script: what counts for him, it seems, is improvisation and invention, and the search for authenticity.

I would like to make a final preliminary comment about "commitment" within the ecosystem of contemporary French cinema. In the mid-1990s, as Depardieu's mythic status was becoming firmly established, a renewed political consciousness emerged among French filmmakers. This awareness hinged on a commitment to engage on some level with "the political", whether that be ethnicity and exclusion, fracture sociale or the failures of multiculturalism. Moreover, several filmmakers and actors (including Mathieu Amalric, Jacques Audiard, Pascale Ferran and Sandrine Veysset) became heavily involved with protests in early 1997 against repressive immigration legislation. Depardieu always appeared apolitical at this time, rarely stepping into the political sphere and eschewing overt political engagement. In more recent times, he has shown a willingness to engage with contemporary events, through his criticism of French tax laws and of the ruling class, not to mention his generic antiAmericanism, but these are primarily localized or personal struggles and his involvement has been sporadic. The broader depoliticized content of Depardieu's pronouncements suggests that he has rarely sought to claim a certain form of commitment through his films or pose social

\footnotetext{
${ }^{16}$ David Krasner, Method Acting Reconsidered: Theory, Practice, Future (New York: Palgrave, 2000), p. 5.
} 
questions through them. Instead, Depardieu's activism, or political engagement, can be located tangentially through the roles he chooses. More and more, he has become the "living embodiment of a raw physical France of farm and industry, of its crashing and crushed history of dealing force and bearing the blows of force". ${ }^{17}$ As France has been buffeted by the iniquities of neo-liberalism and austerity drives, Depardieu's later performances nostalgically remind French audiences of his earlier national heritage symbol roles, providing reassurance in the face of ongoing crises.

\section{A series of moments: Depardieu and heritage cinema}

A new Depardieu persona materialized around the end of the 1980s that focussed on the recreation of historical heroes and characters that formed part of a growing genre of French cultural super-productions. These films were examples of "heritage" films, the popular genre that emerged in French cinema in the course of that decade and that deployed grand sets, meticulous period costumes and hundreds of extras in small acting roles. These films told stories about French history and constructed particular notions of French national identity for domestic and international audiences through both mainstream and art-house productions. This positioning of Depardieu as the personification of French national identity through the portrayal of its historical figures has been viewed as a nostalgic turn to the past (itself a general symptom of postmodernism) but also as a new phase in his career in which Depardieu works through a series of artistic and political processes. For instance, in Bruno Nuytten's Camille Claudel (1988), Depardieu plays the sculptor Auguste Rodin, who takes Claudel (Isabelle Adjani) as his muse and then lover. Because the film focuses on Claudel's career and her eventual descent into madness, less emphasis is placed on Rodin's artistic accomplishments and professional practices. Yet if Depardieu's star persona is marginalized at the expense of Adjani's, his

\footnotetext{
${ }^{17}$ Pinkerton, 2017.
} 
signature blend of ferocity and sensitivity remains undiluted. His approach to the artistic process is energetic. He hammers and chisels stone, pieces of marble flying into his face. He roughly thumbs human forms out of clay. These are acting tics that nostalgically remind the spectator that Rodin is a "Great Man"; in film biopic terms, a subject who is "posed as a visionary with a pure one of a kind talent or idea who must overcome opposition to his idea or even just to himself". ${ }^{18}$ Depardieu may not be the star of the show in Camille Claudel, but as Rodin, his devotion to his profession and his wider contribution to the French patrimoine are represented in the intensity of these gestures.

Similarly, in the TV version of Alexandre Dumas's Le Comte de Monte Cristo (Josée Dayan, 1998), Depardieu, as Edmond Dantès, interweaves the use of body language, modulations in his voice and a cold hard stare to form a character who interests us yet frightens us at the same time. The opening moments of the first episode are an example of this combination of corporeal presence, rhythm and vocal texture. In voiceover, Dantès outlines the plot (these words do not exist in the Dumas original):

Crois-tu que j'aime être le comte de Monte Cristo? C'est un homme terrible, impitoyable et froid. Mais ce n'est pas moi qui ai voulu devenir cet homme-là. Moi, il me suffisait d'être Edmond Dantès, je n'attendais rien d'autre de la vie, mais ils m'en ont empêché. Villefort, Morcerf, Danglars et même l'autre larve de Caderousse, qui savait tout et qui n'a rien dit. En essayant de tuer le jeune marin qui ne demandait rien à personne, ils ont fait naître le vengeur qui vient leur demander des comptes. Eh bien, tant pis pour eux.

The actor is framed in a medium close-up, and he looks off-left, as if recalling a long-forgotten memory. The mouth is tightly closed, set in a scowl. He does not blink. Only when he says "larve" does his intonation change, from cool and measured to disdainful and dismissive. Even as Dayan's camera pulls back and away from him, Depardieu remains motionless. This moment of stillness will contrast to the many later examples of assertive action by Dantès and reminds

\footnotetext{
${ }^{18}$ Dennis Bingham, Whose Lives Are They Anyway?: The Biopic as Contemporary Film Genre (New Brunswick, NJ \& London: Rutgers University Press, 2010), p. 7.
} 
us that stillness as much as movement is what defines Depardieu's tight-knit relationship between the camera and the space around him. ${ }^{19}$

We see this tentativeness again in Dayan's 2000 TV adaptation of Les Misérables, in which Depardieu plays Jean Valjean. The adaptation's erratic release strategy adds a secondary layer to our discussion of hesitancy and motion. Initially, a four-hour version was released in French, and then a heavily edited two-hour version was released shortly afterwards in English, with the French-speaking actors reading their lines a second time in English (rather than resorting to dubbing). The effect is jarring — not least because the film is halved in length and thus omits key scenes from Hugo's original text. ${ }^{20}$ A comparison of the French and English versions of the scene in which Valjean steals the chimney sweep's coin on the open road and refuses to return it demonstrates how Depardieu's acting subtly changes depending on the language spoken. In the French version, he speaks more softly and with more authority, denying that he has the coin, and then bursts into anger as he chases the boy away, shouting "Tu m'embêtes avec ta pièce de quarante sous". In the English version, this line becomes "You and your coin are starting to get on my nerves", and Depardieu delivers it more angrily and faster, but with far less vocal control than in the original. What emerges here are two different types of Depardieu performance of the exact same lines, with the same blocking and camera placement. In the French version, he is able to concentrate on the interaction with the other actor and convey a sense of menace; in the English version, the faster-paced dialogue between the two actors is minimalized as both are concentrating on delivering their lines in a second

\footnotetext{
${ }^{19} \mathrm{~A}$ further example of this interplay between stillness and movement is illustrated in the opening scenes of Balzac - La Passion d'une vie (Josée Dayan, 1999), a two-part TV series for TF1 that focuses on Balzac's literary career. At the very start of the film, we see Depardieu/Balzac recently deceased, lying on a bed; a flashback transports us back a number of years to his printing workshop, where he flamboyantly welcomes his mother and reveals his literary aspirations.

${ }^{20}$ Depardieu's heavily accented English in the condensed version here reminds us that when he switches to this second language (Green Card [1990]; 1492: Conquest of Paradise [1992]; My Father the hero [1994]) he frequently "seems limited in the range of volume and speed at which he can deliver his lines". Chris Mann, "Depardieu in Australia: A question of voice over image?", in Jane Warren, Colin Nettelbeck and Wallace Kirsop (eds), Australian and French Connections: A Century of Cinema, (Melbourne: Institute for the Study of FrenchAustralian Relations, 1996), pp. 75-80, (p. 78).
} 
language with precision. Depardieu's normally expressive facial expressions are also diminished in the English version because of a slight change in eyeline matching. Acting in English does not turn Depardieu into a "bad" actor; instead, it modulates his acting style and encourages us to tune in to a different set of vocal and aural details.

To appreciate the moment-by-moment development of an actor's performance, Andrew Klevan advises the spectator to "slow down, stop and dwell, so that we can savour the intensity of an interaction, an intonation or an expression [...] and reflect on the resonance". ${ }^{21}$ As these brief examples suggest, Depardieu's commitment to shaping psychologically and physically meticulous portrayals of historical figures - and the symbolic value they impart—works in tandem with an energetic performance style. It is by "slowing down" and "reflecting" that we can get closer to the essence of Depardieu.

\section{Danton}

Depardieu's commitment to a system of performance that is simultaneously internalized and externalized is exemplified in his earliest incarnation of an historical figure. Polish director Andrzej Wajda's 1983 film Danton dramatizes the power struggle between Georges Danton (Depardieu) and Maximilien Robespierre (Wojciech Pszoniak) during the French Revolution, and traces their clash of ideology and personality-Robespierre is the aloof, ascetic disciplinarian intent on upholding the Terror, Danton the charismatic man of the people full of romantic ideals about the Revolution.

Danton marks a critical juncture in Depardieu's career. It signals a softening of the working-class loubard image that he had cultivated in a series of roles in the late 1970s and heralds a shift towards the incarnation of French historical and literary figures. Vincendeau notes how Depardieu's association with post-1970s auteur cinema-and its emphasis on

\footnotetext{
${ }^{21}$ Andrew Klevan, Film Performance: From Achievement to Appreciation (London: Wallflower Press, 2005), p. 103.
} 
"abstract explorations of the human condition"-allows the actor's tragic persona to emerge more cohesively in these subsequent roles. ${ }^{22}$ This is certainly true in the case of Danton, where the incompatibility between Danton's intellectualism and Robespierre's pragmatism leads to the former's execution. While Danton's brash arrogance frames him as an imperfect manifestation of French revolutionary values, he is nevertheless configured as a literal personification of liberté, égalité and fraternité. In this way, Depardieu's performance highlights how the most accomplished French heritage films will always valorize their central protagonists as great French historical figures, but also question their individual motivations.

The central conflict in Danton relies on the physical and vocal differences between Danton and Robespierre to present their contrasting ideological stances. Wajda sets up a series of oppositions. Danton is a free-spirited, impressive figure, full of joie de vivre and prone to energetic speeches. This stands in sharp contrast to his rival Robespierre's obdurate, intransigent personality. ${ }^{23}$ The facial features of both actors accentuate these differences: Depardieu's are open and warm; Wojciech Pszoniak's are frigid and angular. Wajda has described the film as "a strong, violent, dramatic story, based on forceful characters who helped change history". ${ }^{24}$ Much of this forcefulness is in evidence in a series of intensely psychological discussions between Danton and Robespierre as they debate politics and two differing forms of the Revolution.

Depardieu embodies the sensibilities of Danton by relying on his large body frame, his loud brash voice and his entertaining personality to produce in the audience a sense of wonder regarding the character. He is accorded a typical star entrance, arriving (in the twenty-third minute) for a daily sitting of the National Convention. This delayed appearance $-\mathrm{a}$ frequent

\footnotetext{
${ }^{22}$ Vincendeau, "Gérard Depardieu: The Axiom of Contemporary French Cinema", p. 355.

${ }^{23}$ Depardieu's other film from 1983 was the comedy hit Les Compères, in which he also plays one half of an "odd couple" male duo, alongside Pierre Richard. In Francis Veber's film, Depardieu is this time cast as the uptight journalist, with Richard the accident-prone depressive.

${ }^{24}$ Gideon Bachmann, "Man of Heart: Andrzej Wajda", Film Quarterly, 36: 2 (Winter 1982/1983), 2-5 (pp. 2-3).
} 
cinematic convention to enhance star quality and generate maximum audience anticipation and desire — makes Danton/Depardieu appear all the more spectacular. His unruffled body language and slow, deliberate pacing through the hall are offset by Westermann (Jacques Villeret) and his frantic movements and urgent, whispered warnings of a coup against Danton by Robespierre and the Committee of Public Safety. The camera here frames Depardieu in a series of alternating medium close-ups and close-ups as opposed to the mid-shots reserved for the other characters (Westermann, Desmoulins, Philippeaux, Bourdon, etc). Danton is now the centre of attention, and will remain so whenever he is on screen.

Another illustration of Depardieu's ability to pivot between internal and external modes comes towards the end of the film. At Danton's final trial before the Revolutionary Tribunal, Depardieu makes an impassioned appeal before being sentenced to execution by a decree of the Committee of Public Safety. Once again, body and voice align to create a performance that encapsulates Danton's internal political struggles. His voice intensifies when he turns on his accusers, then drops to a whisper when he addresses them about the failure of the Revolution. There is little cutting in the scene- the camera stays fixed on Depardieu, tracking alongside him as he moves, or fixing on his face as he addresses the tribunal. At the end, all that remains is his hoarse, almost inaudible voice cracking under the emotional strain. Yet the voice still retains absolute control, becoming louder and more forceful as his anger and resolve heighten. The body too is constantly modulating between stillness and a fixed gaze on the one hand, and on the other, wild gestures designed to provoke the Committee. Both these scenes epitomize how Depardieu's heritage constructions of masculinity and of authority are in constant flux. The voice rises and falls, the body language is at turns gesticulatory or inert. David Denby noted that, in Danton, "speech is action". ${ }^{25}$ In Depardieu's case, so too is body movement. Both voice and body are deployed to lend reassurance and dependability to the heritage genre - the view

\footnotetext{
${ }^{25}$ David Denby, “Danton Lives”, New York Magazine, 10 October 1983, p. 87.
} 
of French history on display is underpinned by Depardieu's linguistic dexterity and his robust physical presence.

When, where and how actors move are critical to Danton's dramatic patterns. Danton has invited Robespierre to dinner, and they will shortly argue over who can claim to be the voice of the people. Before Robespierre arrives, Danton plays the stage manager, fretting over the food, reminding his servants that Robespierre likes only blue flowers, and anxiously preparing the private suite for their intimate encounter. In these early moments, Danton is presented as an epicurean, fond of lavishly prepared meals and camaraderie. Read retrospectively, the scene foreshadows Depardieu's future lifestyle of consumption and excess that will see fluctuations in weight and appearance. Already, the discourse that will characterize Depardieu in the later part of his career - a personality of colossal proportions whose lust for life is unbounded-is being established by Wajda and the actor here. Just as Danton the revolutionary seems to be more interested in wine and good food than in committed politics, so too does Depardieu embrace over-indulgence as a mark of authentic Frenchness.

He tastes the turbot, the quails and the capers, jabbing his fingers into sauce, licking them, and revealing his pleasure and excitement through a series of childlike gestures and noises. This is a vastly different type of performance from that in the two aforementioned scenes at the National Convention and the Committee for Public Safety. There, the emphasis was on control and authority, and on the spectacularized display of the body and voice to multiple spectators. Here, Depardieu reveals Danton's private insecurities as he fusses over the meal. The gestures are quicker, less meticulous, the vocal patterns breathier (note the repeated use of "oui oui" to indicate pleasure or agreement). When Robespierre finally arrives, he opens the door to see Danton rapidly drinking glasses of wine in an attempt to settle his nerves. Danton is not aware that he is being watched; only after finishing the third glass does he turn to see Robespierre at the door. Depardieu's response here is a wonderful example of comic timing-he knows that 
the notoriously ascetic Robespierre has seen him drinking but turns to face him with a knowing smile. Martha Sherrill has described this type of Depardieu smile as "imbecilic", deliberately crafted to impart a "mythic ugliness [...] which makes you care about him". ${ }^{26}$ This effect is magnified by Depardieu's reaction: he pauses for a second, holds out his arms to embrace Robespierre, and utters a gasping "hé”. For a brief moment, Depardieu is directly addressing Robespierre (and the spectator) and deconstructing the iconicity of Danton: Depardieu is no longer playing a crucial historical figure in a heritage drama, but a version of himself that will ultimately coalesce into a symbolic social identity that embraces multiple markers of Frenchness.

The irony of this scene is that Robespierre chooses not to eat, despite Danton eagerly displaying the platters of lavishly prepared food. Robespierre's refusal allows Depardieu to exhibit more comic timing — he lifts plates and Robespierre declines, with Depardieu muttering each time "et ça?". He bites into the quail to reassure Robespierre that the food has not been poisoned, adding a fey "Mmm... c'est bon, ça". Wajda cuts back to Robespierre so that we see his stony-faced reaction to Danton's antics here. It is surprising to see a scene like this smuggled into a serious costume drama. It reveals to a startling degree the ability of Depardieu to impart all manner of droll intonations, gestures and rhythms within the seemingly rigid parameters of the heritage genre. This comedic interlude reveals that Depardieu's performative presence cannot be contained. Danton's social anxiety in the early part of the scene is exemplified by his excessive eating, nervous laughter and the enunciation of a question to Robespierre- “Tu n'as vraiment pas faim?"- as if it were a punchline. When Robespierre politely declines once more, Danton simply pushes the plates, glasses and crockery to the floor.

26 Martha Sherrill, "The Myth of Gérard Depardieu", The Washington Post, 11 April 1990, https://www.washingtonpost.com/archive/lifestyle/1990/04/11/the-myth-of-gerard-depardieu/5084c47c-089443a1-876f-5c5614cf5b0b/ (accessed 22 October 2020). This smile is one we see in many of his comedy films, from Le Placard (2001) to Boudu (2005). 
The rest of the scene plays out in real time-Danton and Robespierre talk politics, but Danton continues to drink, refilling his glass as soon as it is empty. Before our eyes, Depardieu is drinking himself into a stupor while simultaneously extolling the virtues of the people and the Republic. He becomes progressively wide-eyed, his voice less sure of itself, his gestures less precise. He coughs and slurs his words, but then comes the pivotal moment of the scene: a violent outburst at Robespierre. Drunk and uninhibited, he moves close into Robespierre's face, upsets his carefully coiffed wig, and admonishes him for being disconnected from and dismissive of the French people. Finally, drunk and exhausted, he falls asleep in Robespierre's arms.

Depardieu here captures Danton's sense of rebellion and anti-establishment posturing through moments of comedic excess. Vincendeau has noted that Depardieu "is perfect for the heritage genre" because " "the larger-than-life' aspect of his persona $[\ldots]$ fits roles which are [...] about fame, display and acting — in short, about stardom". ${ }^{27}$ His incarnation of Danton is thus doubly successful because the personal excesses and expansive public persona that Depardieu brings to the role are a fictionalized version of the actor himself.

\section{Conclusion}

It is worth returning to Haskell's comments made in 1978 about Depardieu: tactile, curious, a child discovering the world, inching and shoving along, grasping, eating, touching, coming to physical terms with everything in sight. Is she not describing his performance as Danton here? The moments on which we have lingered serve to unify an image of Depardieu as a committed actor whose performative, physical and vocal nuances establish a coherent identity that would be redeployed throughout the 1980s and 1990s in a range of heritage and historical roles. His subsequent heritage roles in the likes of Jean de Florette (1986), Cyrano de Bergerac (1990)

\footnotetext{
${ }^{27}$ Vincendeau, Stars and Stardom in French Cinema, p. 231.
} 
and Tous les matins du monde (1991) build on the foundations laid down in Danton, and display varying degrees of the tactility and propulsion first identified by Haskell. A close appraisal of Depardieu's performative style shows in a fresh light the internal/external dynamic that characterizes his most notable roles and shows how he is constantly circulating between auteur and commercial cinema, between heritage and popular genres, "diffract[ing] his image in order to reassemble it to even greater effect". ${ }^{28}$ This, ultimately, is the true commitment of Depardieu: a pledge to keep on working, une force qui va who reassures us with his longevity and vitality.

The University of Adelaide

\footnotetext{
${ }^{28}$ Gwénaëlle Le Gras, "Major Stars, the Heritage Film, and Patrimonial Values in Contemporary French Cinema", in Alistair Fox, Michel Marie, Raphaëlle Moine and Hilary Radner (eds), A Companion to Contemporary French Cinema (Chichester: Wiley Blackwell, 2015), pp. 314-332 (p. 323).
} 